\title{
Pedagojik Formasyon Programı ile Lisans Eğitimi Fen Bilimleri Öğretmen Adaylarının Dijital Okuryazarlık Düzeylerinin İncelenmesi
}

\author{
Examining the Digital Literacy Levels of Undergraduate Science \\ Education and Pedagogical Formation Programme Preservice Teachers
}

$$
\text { DOI=10.17556/jef.01175 }
$$

\section{Oğuz ÇETiN**}

\section{Özet}

$\mathrm{Bu}$ çalışmanın amacı, pedagojik formasyon programı fen bilimleri öğretmen adayları ile lisans eğitimi fen bilgisi ögretmen adaylarının dijital okuryazarlık düzeylerinin çeşitli değişkenler çerçevesinde araştırılmasıdır. Çalışmada genel tarama modeli kullanılmış, çalışma grubunu Niğde Üniversitesi, Eğitim Fakültesinde 2014-2015 eğitim-öğretim yılında pedagojik formasyon programında öğrenim gören 124 fen bilimleri öğretmen adayı ile lisans son sınıfta öğrenim gören 78 fen bilgisi öğretmen adayı oluşturmuştur. Veri toplama aracı olarak "Kişisel Bilgi Formu" ve "Öğretmen Adaylarının Dijital Okuryazarlık Düzeylerini Belirleme Ölçeği" kullanılmıştır. Çalışmadan elde edilen bulgular ışığında; öğretmen adaylarının kendilerini dijital okuryazarlık bakımından yeterli seviyede gördükleri, erkek öğretmen adaylarının kadın öğretmen adaylarına ve lisans eğitiminde öğrenim görmekte olan öğretmen adaylarının pedagojik formasyon programında öğrenim gören öğretmen adaylarına göre dijital okuryazarlık düzeylerinin daha yüksek olduğu, Internet kullanım sıklığının dijital okuryazarlık düzeyini olumlu yönde etkilediği sonucuna ulaşılmıştır.

Anahtar Sözcük: öğretmen adayları, pedagojik formasyon programı, dijital okuryazarlık, teknoloji.

\section{Abstract}

The purpose of this research is to study the digital literacy levels of pedagogical formation programme and undergraduate science education preservice teachers within the frame of multiple variables. General survey model is used in the study. The population of the study is comprised of 78 fourth-grade undergraduate science education preservice teachers and 124 science education preservice teachers who are under the programme of pedagogical formation in the Education Faculty of

* Yrd. Doç. Dr., Niğgde Üniversitesi, Eğitim Fakültesi, Bilgisayar ve Öğretim Teknolojileri Eğitimi Bölümü, e-posta: oguz.cetin@ windowslive.com. 
Niğde University during 2014-2015 school year. "Personal Information Form" and "Scale to Determine Digital Literacy Levels of Preservice Teachers" was used. In the light of the findings acquired from the study; it was determined that all of the preservice teachers think that they are proficient enough in terms of digital literacy levels, that the digital literacy levels of male preservice teachers were higher when compared to female preservice teachers just as the digital literacy levels of preservice teachers who are receiving undergraduate education were higher when compared with the digital literacy levels of preservice teachers receiving education under pedagogical formation programme. It was also concluded that having continious access to Internet has a positive impact on digital literacy levels of the preservice teachers.

Keywords: preservice teachers, Pedagogical formation programme, digital literacy, technology.

\section{Giriş}

Dijital dönem olarak adlandırılan bu dönemde dijital teknolojilerin hızlı gelişimi, dijital ortamlardaki problemleri çözmek için bireyleri teknik, bilişsel ve sosyolojik anlamda beceri seviyelerini arttırma zorunluluğu ile karşı karşıya getirmektedir. Bu beceriler alan yazında "dijital okuryazarlık" olarak adlandırılmaktadır (Acharya ve diğer., 2015; Eshet-Alkalai, 2004; Eshet-Alkali \& AmichaiHamburger, 2004; Eshet, 2005). Dijital okuryazarlık dijital aygitları kullanabilmek için gerekli olan teknik yetenekten daha fazlasını içermekte, web ortamında gezinmek, kullanıcı ara yüzlerinin şifresini çözmek, veri tabanları ile çalışmak ve sohbet odalarında sohbet etmek gibi dijital ortamlardaki farklı görevleri yerine getirmeyi sağlayan pek çok bilişsel beceriyi kapsamaktadır. Bu bağlamda dijital okuryazarlık içinde bulunduğumuz teknolojik dönemde bir hayatta kalma becerisi haline dönüşmektedir (Eshet-Alkali \& Amichai-Hamburger, 2004).

Dijital okuryazarlığın alan yazında ifade edilen tanımları incelendiğinde, tek başına ya da birleştirilmiş şekilde anlamların teknik, bilişsel, psikolojik ve/veya sosyolojik bağlamda tartışıldığ görülmektedir (Ng, 2011). Örneğin Eshet-Alkalai (2004) dijital okuryazarlığı farklı okuryazarlığın birleşimi olarak tanımlamıştır. Bunlar; foto-görsel okuryazarlık (resim, diyagram ve grafik gibi görsel temsilleri okuma yeteneği), çoğaltma okuryazarlığı (kopyalama, çoğaltma ve mevcut bilgileri yeniden yapılandırma yeteneği), bilgi okuryazarlığı (kaynakları güvenirlik, doğruluk ve özgünlük boyutunda değerlendirebilme yeteneği), dallanma 
okuryazarlığı (doğrusal olmayan bir şekilde bilginin anlamını oluşturma ve bilgiye ulaşma yeteneği) ve sosyo-duygusal okuryazarlık (sanal gerçeklikte başkaları ile etkili bir şekilde iletişim ve işbirliği kurabilme yeteneği) şeklindedir. Dijital okuryazarlığın daha genel bir tanımı olarak Martin (2005: 135) tarafından yapılan tanım oldukça açıklayıcı niteliktedir. Martin (2005: 135) dijital okuryazarlığı şu şekilde tanımlamaktadır;

Dijital okuryazarlık, bireylerin dijital araçları ve olanaklarını; dijital kaynakları uygun bir biçimde tanımlama, erişim, yönetme, uyum, değerlendirme, analiz ve sentez, yeni bilgiyi yapılandırma, medya ifadeleri oluşturma ve başkaları ile iletişim kurma, özel yaşam durumları bağlamında yapıcı sosyal eylemlerde bulunma ve bu süreçte yansıtma farkındalı̆̆

Tanım irdelendiğinde, dijital okuryazarlığın teknik, bilişsel ve sosyal bakış açılarından beslendiği görülmektedir. Bu noktada dijital okuryazarı bir bireyin teknik, bilişsel ve sosyal açıdan temel becerilere sahip olması beklenmektedir. Bilgisayarı etkin kullanabilmeli, Web ortamındaki uygulamalara hâkim olmalı, bir problem ile karşılaştığında çözüm için sahip olduğu becerileri ne şekilde ve hangi zamanda kullanması gerektiğini bilmelidir. Bununla birlikte dijital okuryazarlık dijital teknolojileri kullanmadan ziyade bilgiyi bulma, kullanma, değerlendirme, yeni bilgi oluşturma ve bilgiyi sunma gibi becerileri de kapsamaktadır (Kazu \& Erten, 2014).

Günümüzde bilgi üretiminin hılı bir biçimde artışı, bilgi kaynaklarının ise genel itibari ile dijital ortamlar olması, bununla birlikte Internet sayesinde bireylerin ilgi alanına giren herhangi bir bilgiye çok kısa sürede ulaşabilmesi, dijital okuryazarlığın önemini her geçen gün daha da fazla arttırmaktadır. Bilgiye Internet gibi dijital teknolojileri kullanarak ulaşabilmek bazı temel becerilerin yanı sıra, var olan bilgi hakkında analitik düşünebilme, sorgulama ve etkin değerlendirme yapabilme becerilerine sahip olmayı da gerektirmektedir (Akkoyunlu \& Soylu, 2010). Bu yüzden dijital okuryazarlık becerileri aynı zamanda bütün öğretim programı alanlarında kapsamlı ve uygulanabilir bileşenler olarak karşımıza çıkmaktadır (Ng, 2011). Bu noktada dijital okuryazarlığın geliştirilmesi, dijital teknolojilerin doğru kullanımı boyutunda eğitim kurumlarına ve öğretmenlere büyük sorumluluklar düşmektedir. Eğitim kurumları ve öğretmenler dijital uçurum olarak tabir edilen 
bilgi ve iletişim teknolojileri alanında ülkeler arasındaki ve ülkeler içindeki eşitsizliğin (Akkoyunlu \& Soylu, 2010) azaltılmasında, bireysel becerilerin arttırılarak bilgi toplumuna uyum sağlamış bireylerin yetiştirilmesinde çok önemlidir. Bilindiği üzere eğitimin işlevlerinden bir tanesi toplumun gereksinimleri doğrultusunda bireyler yetiştirmektir. İçinde bulunduğumuz toplum yapısı dikkate alındığında, bilgi çağına uyum sağlamış, bu toplumun beklentilerini karşılayan eğitim sistemleri oluşturulmalıdır. Dijital teknolojiler öğrenme ortamlarının niteliğini arttıracak şekilde öğretmen ve öğrenciler tarafindan etkin olarak kullanılmalıdır. Öğrenciler ancak dijital okuryazar olurlarsa dijital teknolojileri bilgiye ulaşma, düzenleme, geliştirme ve değerlendirme boyutunda dijital yetkinlik sağlayabilirler (Timur, Timur, \& Akkoyunlu, 2014). Bu durumun farkında olan Avrupa Birliği ülkeleri, Avrupa Birliği e-öğrenme programı çerçevesinde 2006 yılında "Dijital Okuryazarlık Sistemlerinin Çözümlenmesi” başlıklı bir çerçeve belgesi hazırlamıştır (Rosado \& Bélisle, 2006).

Alan yazın incelendiğinde ise eğitimbilim boyutunda dijital okuryazarlık kavramına ilişkin çalışmaların özellikle son on yıl içerisinde gelişme içerisinde olduğu görülmektedir. Çalışmaların bazıları dijital okuryazarlık kavramının kuramsal boyutu üzerine odaklanmıştır. Dijital okuryazarlığın ne olduğu, alt boyutları, dijital okuryazarlık becerilerinin tanımlanması, becerileri arttırmaya yönelik ders önerileri, vb. konularda yapılmış çalışmalar mevcuttur (Bawden, 2001; Eshet-Alkalai, 2004; Hjørland, 2010; Lankshear \& Knobel, 2008; Ng, 2011; O'Byrne, 2016; Shand, Winstead, \& Kottler, 2012). Bununla birlikte bu çalışmaya dayanak olan betimsel olarak gerçekleştirilmiş çalışmalar da mevcuttur. Örneğin Bhatt (2012) doktora çalışması kapsamında bir İngiliz kolejinde Sara isimli bir öğrencinin dersine yönelik yazma değerlendirmelerini incelemiş, bu değerlendirmelerde ortaya çıkan dijital okuryazarlık deneyimlerini araştırmıştır. Çalışma öğrencinin gündelik hayatında etkin bir biçimde kullandığı dijital araçları sınıf pratiğine nasıl dönüştürdüğünü araştırmaktadır. Çalışma sonunda elde edilen bulgular kişisel anlamda elde edilmiş dijital okuryazarlık becerilerinin sınıf temelli dijital okuryazarlık etkinliklerine taşınmasının, öğrenenlere günlük hayatındaki dijital okuryazarlık uygulamaları ile dersin gerektirdiği 
uygulamalar arasında bağ kurulmasına olanak tanıdığı sonucunu ortaya çıkarmıştır.

Burnett 2011 y1lında gerçekleştirmiş olduğu çalışmada öğretmen adaylarının birden çok etki alanında dijital uygulamalarına yönelik nasıl bir algı oluşturduklarını keşfetmek amacı ile bir yaklaşım tasarlamıştır. Yedi öğretmen adayı ile yedi aylık bir süreçte onların okullarındaki dijital okuryazarlık uygulamalarını temel alan görüşmeler gerçekleştirmiştir. Bu yedi aylık sürede öğretmen adayları "Görüşlerin Değişimi" isimli bir modül ile eğitim almışlardır. Çalışmanın sonunda dijital okuryazarlık becerilerine yönelik yeni pedagojileri araştıracak ve geliştirecek süreç meydana getirildiği takdirde, bu becerilerin öğretmen adayları tarafindan hayatlarının değişik aşamalarında deneyimlendirerek kullanılabileceği sonucu ortaya çıkmıştır. Kajee ve Balfour (2011) Güney Afrika Üniversitesi'nde öğrenim gören 16 tanesi farklı ülkelerden olmak üzere 37 öğrenci ile gerçekleştirmiş oldukları nitel araştırmanın sonunda, öğrencilerin dijital aygıtları sembolik değerlere sahip olma olarak algıladıkları, bu aygıtlarla küresel sermayeye erişim sağladıkları sonucuna ulaşmışlardır.

Eshet-Alkali ve Amichai-Hamburger (2004), 20 11. Sinıf, 20 üniversite 3. Sınıf ve 20 üniversite mezunu toplam 60 kişi ile gerçekleştirdiği çalışmada dijital okuryazarlık düzeylerini EshetAlkalai (2004) tarafindan ifade edilen ve yukarıda verilmiş olan alt boyutlar çerçevesinde araştırmışlardır. Çalışmanın sonunda dijital okuryazarlık düzeylerinin gruplar bazında farklılık gösterdiği, genç bireylerin yaşça daha büyük bireylere göre dijital okuryazarlık düzeylerinin daha yüksek olduğu sonucuna ulaşmışlardır. Dijital okuryazarlığın bilişsel becerilerin ve stratejilerin karmaşıklığını anlanmasını sağlayan güçlü bir araç olduğuna vurgu yapmışlardır. Benzer şekilde Akkoyunlu ve Soylu (2010), Kazu ve Erten (2014) ve Timur ve diğer. (2014) öğretmen ve öğretmen adayları ile gerçekleştirmiş oldukları birbirine benzer çalışmalarda, öğretmenlerin ve ögretmen adaylarının dijital yetkinlik düzeylerini farkındalık, motivasyon, teknik erişim ve yetkinlik alt boyutlarında incelemişlerdir.

Kıyıcı 2008 yılında gerçekleştirmiş olduğu doktora tez çalışmasında farklı üniversitelerde öğrenim gören öğretmen 
adaylarının dijital okuryazarlık düzeylerini dijital okuryazarlık, bilgisayar okuryazarlığı, bilgi okuryazarlığı, teknoloji okuryazarlığı ve medya okuryazarlığı bağlamında çeşitli değişkenler açısından karşılaştırmış, öğretmen adaylarının dijital okuryazarlık düzeylerinin cinsiyetlerine, bilgisayar ve Internet'e sahip olup olmama durumlarına, bölümlerine, yerleştirme puan türlerine, aile gelir düzeylerin eve kişisel gelir düzeylerine göre farklılık gösterdiği sonucuna ulaşmıştır. Yine İşçioğlu ve Kocakuşak (2012) sınıf öğretmeni adayları ile gerçekleştirmiş oldukları benzer bir çalışmada, öğretmen adaylarının dijital okuryazarlık düzeylerinin yüksek olmasına karşın, kendi alan derslerinde ve ileride öğretmenlik hayatlarında teknolojiyi kullanma konusundaki algılarının düşük olduğu sonucuna ulaşmışlardır.

Bilindiği üzere ülkemizde öğretmenlik mesleğine yönelik akademik eğitim, eğitim fakülteleri bünyesinde verilmektedir. Fakültelerde yürütülen dört yıllık lisans eğitiminin yanı sıra 20132014 Eğitim Öğretim Y1lı itibari ile pek çok eğitim fakültesi bünyesinde pedagojik formasyon eğitimi sertifika programları açılmıştır. 2015-2016 Eğitim-Öğretim Yılı'nda da 5. dönem pedagojik formasyon eğitimi sertifika programı yürütülmektedir. Farklı fakültelerde öğrenim gören ya da mezun konumundaki öğrenciler bu program ile öğretmen olma yetkinliği kazanmaktadır. Pedagojik formasyon sertifika programı ders içerikleri incelendiğinde, zorunlu olan "Ögretim Teknolojileri ve Materyal Tasarımı" dersi ile seçmeli olan "Eğitimde Teknoloji Kullanımı" dersi kapsamında öğretmen adaylarına teknoloji kullanımına yönelik beceriler kazandırılmaya çalışılmaktadır. "Eğitimde Teknoloji Kullanımı" dersi seçmeli ders olması nedeni ile her programda açılmamaktadır. Dolayısıyla özellikle pedagojik formasyon programı öğretmen adaylarına dijital okuryazarlık becerilerini geliştirmeye yönelik sınırlı eğitim verildiği düşünülmektedir.

Bununla birlikte dijital okuryazarlık becerileri özellikle fen eğitiminde önemli görülmekte ve bu önem iki temel nedene dayandırılmaktadır. (1) Bilgi ve iletişim teknolojileri geniş yelpazesi ile öğrencilerin fen kavramlarını daha iyi anlamalarını ve daha motive olmalarını, bu durum da daha etkili fen öğretimini sağlamaktadır. (2) Öğrencilerin çalışan bellek bilişsel yükü bilgi ve iletişim teknolojileri 
tabanlı fen öğrenirken azalmaktadır (Ng, 2011). Ayrıca bu teknolojiler ile tasarlanmış olan fen eğitimi bilişsel gelişimi sağlamakta, fen bilimlerini öğrencilerin gerçek yaşam deneyimlerine ilişkilendirmekte, öğrencilerin kendi öğrenmeleri noktasında bireysel yönetim becerileri kazanmasında teşvik etmekte ve veri toplama-sunma olanağı sağlamaktadır (Webb, 2005). Fen eğitimine pedagoji sağlayan bilgi ve iletişim teknolojileri erişimli yapılar; etkileşimli tahta, dijital mikroskoplar, etkileşimli çalışma yaprakları, elektronik laboratuvar defteri, fen Web siteleri, çoklu ortam düzenleyici araçlar, Web 2.0 teknolojileri, simülasyonlar ve veri girişi ekipmanları gibi pek çok donanım ve yazılımı içermektedir ( $\mathrm{Ng}, 2011)$. Bu donanım ve yazılımları ise en başta kullanacak olan kişiler ise dijital okuryazarlığı yüksek ögrretmenler olacaktır.

Dijital okuryazarlığın gündelik hayatta, öğretmenlik eğitiminde ve bir disiplin olarak fen eğitiminde yukarıda ifade edilen önemi dikkate alındığında, pedagojik formasyon programı fen bilimleri öğretmen adayları ile lisans eğitimi fen bilgisi öğretmen adaylarının dijital okuryazarlık düzeylerinin incelenmesi önemli görülmektedir. $\mathrm{Bu}$ doğrultuda bu çalışmanın amacı, pedagojik formasyon programı fen bilimleri öğretmen adayları ile lisans eğitimi fen bilgisi öğretmen adaylarının dijital okuryazarlık düzeylerinin çeşitli değişkenler (cinsiyet, okuduğu öğretmen yetiştirme programı ve Internet kullanım sıklığı gibi) açısından incelemektir. Çalışmanın problemi "Niğde Üniversitesi, Eğitim Fakültesi'nde öğrenim görmekte olan öğretmen adaylarının dijital okuryazarlık düzeyleri çeşitli değişkenler açısından farkl1lık göstermekte midir" şeklinde belirlenmiştir. Lisans eğitimi alan öğretmen adayları ile pedagojik formasyon çerçevesinde eğitim alan öğretmen adaylarının karşılaştırılması özellikle bu çalışmanın odak noktasını oluşturmaktadır. Çalışma yukarıda belirtilen problem cümlesine uygun dört alt problem çerçevesinde ele alınmış ve bulgular da ona göre yorumlanmıştır.

1. Alt Problem: Öğretmen adaylarının dijital okuryazarlık düzeylerine ilişkin puanlarının dağılımı nedir?

2. Alt Problem: Öğretmen adaylarının dijital okuryazarlık düzeylerinde cinsiyetlerine göre farklılıklar var mıdır? 
3. Alt Problem: Öğretmen adaylarının dijital okuryazarlı düzeylerinde öğrenim gördükleri ögretmen yetiştirme programına göre farklılıklar var mıdır?

4. Alt Problem: Öğretmen adaylarının dijital okuryazarlık düzeylerinde Internet kullanım sıklıklarına göre farklılıklar var mıdır?

\section{Yöntem}

\section{Araştırma Modeli}

Pedagojik formasyon programı fen bilimleri öğretmen adayları ile lisans eğitimi fen bilgisi öğretmen adaylarının dijital okuryazarlık düzeylerini çeşitli değişkenler çerçevesinde incelemeyi amaçlayan bu çalışmada, var olan bir durumu olduğu şekli ile betimlemek amacıyla tarama modeli; bu modelde yer alan yaklaşımlardan da genel tarama modeli kullanılmıştır. Karasar (2009:77-79)'a göre genel tarama modeli, evren hakkında genel bir yargıya varmak amacı ile evrenin tümü ya da ondan alınacak bir örneklem üzerinde yapılan tarama düzenlemeleridir. Araştırmada genel tarama modeli kullanılarak pedagojik formasyon programı fen bilimleri öğretmen adayları ile lisans eğitimi fen bilgisi öğretmen adaylarının dijital okuryazarlık düzeyleri farklı değişkenler açısından betimlenmeye çalışılmıştır.

\section{Çalışma Grubu}

Araştırmanın çalışma grubunu 2014-2015 eğitim-öğretim yılı içerisinde Niğde Üniversitesi Eğitim Fakültesi'nde pedagojik formasyon programında öğrenim gören 124 fen bilimleri öğretmen adayı ile lisans son sınıfta öğrenim gören 78 fen bilgisi öğretmen adayı oluşturmuştur. Çalışma grubu toplam 202 katılımcıdan oluşmaktadır. Çalışma grubunun seçiminde olasılık dışı (amaçlı) örnekleme tekniklerinden uygun durum örneklemesi kullanılmıştır. Uygun durum örneklemesi, araştırma yapılacak katılımcıların sürece dahil edilmesinin kolay olduğu, yakın çevrede bulunan ve araştırmaya gönüllü olarak katılmak isteyen katılımcılar üzerinde yapılan örnekleme olarak tanımlanmaktadır (Ekiz, 2009: 105-106; Erkuş, 2009: 98). Bu yüzden örneklem kavramı yerine çalışma grubu 
kavramı kullanılmıştır. Pedagojik formasyon programının bir yıllık bir öğrenim süresini kapsaması ve programın bitiminde öğretmen adaylarının ögretmenlik yapabilecek yetkinlikte olacak olması nedeni ile formasyon programı öğretmen adayları ile eşit sürede aynı yetkinliğe sahip olacak lisans programından mezun olacak konumdaki son sınıf öğretmen adaylarının çalışma grubuna alınması uygun görülmüștür.

Kat1lımcilardan kendilerine verilen anket formundaki demografik özelliklerini içeren kişisel bilgi formu ile Öğretmen Adaylarının Sayısal Okuryazarlık Düzeylerini Belirleme Ölçeği'ni doldurmaları istenmiştir. Çalışma grubuna dahil edilen 218 öğretmen adayından 202 katılımcının ölçekleri değerlendirmeye alınmıştır. Araştırmada öğretmen adaylarının dijital okuryazarlık düzeylerinin ortaya konması amaçlandığından çözümlemelerde kişisel bilgi formunda yer alan değişkenlere göre karşılaştırmalar yapılmıştır. Çalışma grubunda yer alan öğretmen adaylarına ilişkin demografik özellikler Tablo 1'de yer verilmektedir.

Tablo 1. Çalışma Grubunda Yer Alan Öğretmen Adaylarının Demografik Özellikleri

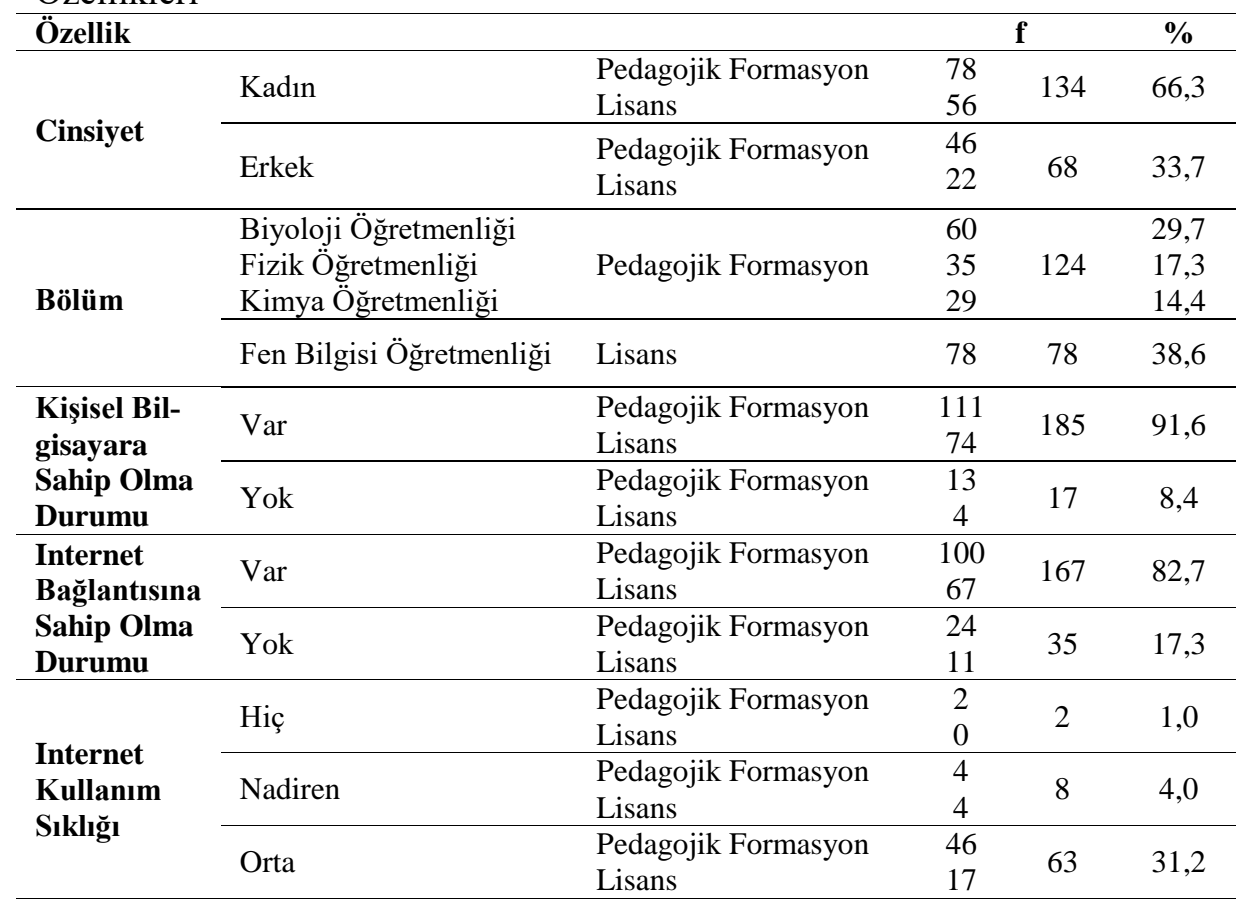




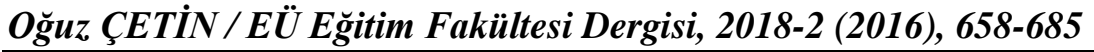

\begin{tabular}{|c|c|c|c|c|c|}
\hline & Sik & $\begin{array}{l}\text { Pedagojik Formasyon } \\
\text { Lisans }\end{array}$ & $\begin{array}{l}34 \\
26\end{array}$ & 60 & 29,7 \\
\hline & Çok Sik & $\begin{array}{l}\text { Pedagojik Formasyon } \\
\text { Lisans }\end{array}$ & $\begin{array}{l}38 \\
31\end{array}$ & 69 & 34,2 \\
\hline TOPLAM & & & \multicolumn{2}{|c|}{202} & 100 \\
\hline
\end{tabular}

Çalışma grubunda yer alan katılımcıların demografik özellikleri incelendiğinde, katılımcıların \%66,3'ünün (134 kişi) kadın olduğu görülmektedir. Öğretmenlik mesleğinin özellikle kadınlar tarafından daha çok tercih ediliyor olmasının bu duruma neden olduğu düşünülebilir. Çalışma grubunda pedagojik formasyon programı çerçevesinde eğitim alan fen bilimleri öğretmen adaylarının oranı \%61,4 (124 kişi) seviyesindedir. Katılımcıların büyük bir çoğunluğu kişisel bilgisayara $(\% 91,6)$ ve Internet bağlantısına $(\% 82,7)$ sahip durumdadır. Katılımcılar Internet'i ise \%63,9 oranında "sık" ve "çok sik" kullanmaktadır.

Kişisel bilgi formunda katılımcılara bilgisayarı ve Internet'i en çok hangi amaçla kullandıkları sorulmuştur. Katılımcıların vermiş oldukları yanıtların bölümler bazında dağılımı Tablo 2'de verilmektedir.

Tablo 2. Çalışma Grubunda Yer Alan Öğretmen Adaylarının Bilgisayar ve Internet'i Kullanım Amaçları

\begin{tabular}{|c|c|c|c|c|c|c|c|c|}
\hline \multirow{4}{*}{ Kullanım Amacı } & \multicolumn{8}{|c|}{ 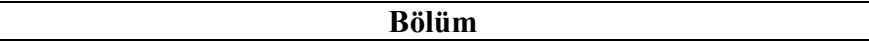 } \\
\hline & \multicolumn{6}{|c|}{ Pedagojik Formasyon } & \multirow{2}{*}{\multicolumn{2}{|c|}{$\begin{array}{c}\text { Lisans } \\
\text { Fen Bilgisi }\end{array}$}} \\
\hline & \multicolumn{2}{|c|}{ Biyoloji } & \multicolumn{2}{|c|}{ Fizik } & \multicolumn{2}{|c|}{ Kimya } & & \\
\hline & $\mathrm{f}$ & $\%$ & $\mathrm{f}$ & $\%$ & $\mathrm{f}$ & $\%$ & $\mathrm{f}$ & $\%$ \\
\hline $\begin{array}{l}\text { Ödev Hazırlama, } \\
\text { Bilgi Toplama }\end{array}$ & 20 & 33,3 & 12 & 34,3 & 9 & 31 & 38 & 48,7 \\
\hline Oyun Oynama & 5 & 8,3 & 3 & 8,6 & 2 & 6,9 & 10 & 12,8 \\
\hline $\begin{array}{l}\text { Sosyal Amaçlı } \\
\text { (chat, sosyal } \\
\text { paylaşım siteleri, } \\
\text { vb.) }\end{array}$ & 23 & 38,3 & 11 & 31,4 & 11 & 37,9 & 18 & 23,1 \\
\hline E-Posta & 10 & 16,7 & 8 & 22,9 & 6 & 20,7 & 11 & 14,1 \\
\hline $\begin{array}{l}\text { Profesyonel } \\
\text { Amaçlı (Web say- } \\
\text { fası, yazılım, oyun, } \\
\text { vb. uygulamalar } \\
\text { geliştirme }\end{array}$ & 2 & 3,3 & 1 & 2,8 & 1 & 3,4 & 1 & 1,3 \\
\hline TOPLAM & 60 & 100 & 35 & 100 & 29 & 100 & 78 & 100 \\
\hline
\end{tabular}

Tablo 2'de yer alan frekans ve yüzdeler incelendiğinde, öğretmen adaylarının bilgisayar ve Internet'i kullanım amaçları birbiri 
ile paralellik arz etmektedir. Öğretmen adayları bilgisayar ve Internet'i genel anlamda ödev hazırlama, bilgi toplama, sosyal amaçlı ve e-posta iletişimi amaçlı kullanmaktadır. Ancak frekans ve yüzdelerde pedagojik formasyon programı öğretmen adayları ile lisans eğitimine devam eden öğretmen adayları arasında oransal anlamda farklılık göze çarpmaktadır. Lisans eğitimine devam eden öğretmen adayları bilgisayar ve Internet'i pedagojik formasyon programı öğretmen adaylarına göre daha yüksek oranda ödev hazırlama ve bilgi toplama amaçlı kullanmaktadır. Buna karşın pedagojik formasyon programı ögretmen adayları ise bilgisayar ve Internet'i daha yüksek oranda sosyal amaçlı kullanmaktadır. Çalışma grubunda yer alan pedagojik formasyon programı öğretmen adayları mezun konumda bulunmaktadır. Lisans eğitimine devam eden öğretmen adayları ise halen öğrenci konumundadır. Dolayısıyla halen öğrenci konumunda olan lisans eğitimi öğretmen adayları etkin olarak sorumlu oldukları derslere ilişkin ödev, proje, vb. çalışmaları gerçekleştirmektedir. $\mathrm{Bu}$ bağlamda yaklaşık olarak yarıya yakınının $(\% 48,7)$ bilgisayar ve Internet'i ödev yapma ve bilgi toplama amaçlı kullandıklarını ifade etmeleri beklenen bir durum olarak ortaya çıkmaktadır. Gerek pedagojik formasyon programı öğretmen adayları, gerekse lisans eğitimi öğretmen adayları bilgisayar ve Internet'i oyun oynama ya da profesyonel amaçlı kullanmayı daha az tercih ettiklerini vurgulamışlardır.

\section{Veri Toplama Araçları ve Verilerin Çözümlenmesi}

Araştırmada veri toplama aracı olarak Çetin ve diğer. (2012) tarafindan geliştirilmiş "Kişisel Bilgi Formu" ile Kıyıcı (2008) tarafindan geliştirilmiş olan "Öğretmen Adaylarının Sayısal Okuryazarlık Düzeylerini Belirleme Ölçeği” kullanılmıştır. Ölçeği uygulamadan önce geliştiricisinden gerekli izinler ve istatistiksel bilgiler alınmıştır. Ölçek beşli Likert tipinde (becerileri gerçekleştirme boyutunda "hiçbir zaman", "nadiren", "bazen", "s1k s1k" ve "her zaman" seçenekleri ile) hazırlanmış olup "bilgisayar okuryazarlığı", "bilgi okuryazarlığı", "teknoloji okuryazarlığı" ve "medya okuryazarlığı”" şeklinde dört alt boyuttan oluşmaktadır. Alt boyutlara ilişkin ölçekte yer alan bazı örnek maddeler Tablo 3'te sunulmaktadır. 
Ŏğuz ÇETíN / Ë̈U Ĕ̌̆itim Fakültesi Dergisi, 2018-2 (2016), 658-685

Tablo 3. Alt Boyutlara İlişkin Ölçekte Yer Alan Bazı Örnek Maddeler

\begin{tabular}{|c|c|}
\hline $\begin{array}{l}\text { Ölçek Alt } \\
\text { Boyutları }\end{array}$ & Örnek Maddeler \\
\hline $\begin{array}{l}\text { Bilgisayar } \\
\text { Okuryazarlığ1 }\end{array}$ & $\begin{array}{ll}\checkmark & \text { E-posta gönderip alabilirim. } \\
\checkmark & \begin{array}{l}\text { Microsoft Word vb. programlarda metin dosyalarında tablo } \\
\text { oluşturabilirim. }\end{array} \\
\checkmark & \begin{array}{l}\text { Microsoft Excel vb. programlarda hesap tablosu dosyalarında } \\
\text { formül yazabilirim. }\end{array} \\
\checkmark & \begin{array}{l}\text { Microsoft Powerpoint vb. programlarda sunum dosyalarının } \\
\text { tasarım şablonlarını değiştirebilirim. }\end{array} \\
\checkmark & \begin{array}{l}\text { Farklı dosya tiplerinin ne anlama geldiğini bilirim (doc, .gif., .html, } \\
\text { ppt., mp3., vb.). }\end{array} \\
\checkmark & \begin{array}{l}\text { Bilgisayar kasası içinde bulunan görünmeyen parçalarını tanımlay- } \\
\text { abilirim. }\end{array} \\
\checkmark & \text { Tarayıcı programlarının (Internet Explorer vb.) temel özeliklerini } \\
\text { kullanabilirim. }\end{array}$ \\
\hline $\begin{array}{l}\text { Bilgi } \\
\text { Okuryazarlığ } 1\end{array}$ & $\begin{array}{ll}\checkmark & \text { Araştırmalarımda farklı bilgi kaynaklarını (ansiklopedi, dergi, re- } \\
& \text { hber vb.) kullanabilirim. } \\
\checkmark & \text { Bilgi kaynak türlerini seçebilirim. } \\
\checkmark & \text { Internet kaynaklarını (Internet sayfaları, elektronik dergiler el- } \\
& \text { ektronik ansiklopediler vb.) kullanabilirim. } \\
\checkmark & \text { Araştırma sonuçlarını sunmam için gerekli yazılımları seçebilirim. } \\
\checkmark & \text { Internet kaynaklarında bulduğum bilgileri eleştirel olarak değer- } \\
& \text { lendirebilirim. } \\
\checkmark & \text { Araştırma yaparken yanlı bilgileri ayırabilirim. }\end{array}$ \\
\hline $\begin{array}{l}\text { Teknoloji } \\
\text { Okuryazarlığ }\end{array}$ & $\begin{array}{ll}\checkmark & \text { Teknolojik problemleri kolaylıkla çözerim. } \\
\checkmark & \text { Yeni teknolojik ürünleri denemeyi severim. } \\
\checkmark & \text { Teknolojik araçların seçiminde güvenliği dikkate alırım. } \\
\checkmark & \text { Teknolojik arçlar ile yeteneklerimi arttırırım. } \\
\checkmark & \text { Teknolojik araçların bakımını gerçekleştirebilirim. } \\
\end{array}$ \\
\hline $\begin{array}{l}\text { Medya } \\
\text { Okuryazarlığ } 1\end{array}$ & $\begin{array}{ll}\checkmark & \text { Hareketli görüntüleri düzenlemek için gerekli donanımları seçe- } \\
& \text { bilirim. } \\
\checkmark & \text { Bilgisayarlı ortamlar için mesajlar üretebilirim. } \\
\checkmark & \text { Televizyonun bütün özelliklerini kullanabilirim. } \\
\checkmark & \text { Fotoğrafları bilgisayar ortamına aktarabilirim. }\end{array}$ \\
\hline
\end{tabular}

Geliştiricinin yapmış olduğu çalışmalarda ölçeğin Cronbach Alpha iç tutarlılık katsayısı ,9798 olarak bulunmuştur. Mevcut çalışmada hem tüm ölçeğin hem de alt boyutlarının Cronbach Alpha iç tutarlılık katsayıları hesaplanmıştır. Buna göre tüm ölçeğin Cronbach Alpha iç tutarlılık katsayısı ,984, alt boyutlarda Cronbach Alpha iç tutarlılık katsayısı bilgisayar okuryazarlığı alt boyutuna ilişkin maddelerde 945 , bilgi okuryazarlığ 1 alt boyutuna ilişkin maddelerde ,955, teknoloji okuryazarlığ 1 alt boyutuna ilişkin maddelerde ,951 ve 
medya okuryazarlığ 1 alt boyutuna ilişkin maddelerde ise ,961 olarak bulunmuştur.

Çözümlemeler için aritmetik ortalamalar, frekans ve yüzdeler belirlenmiş, karşılaştırmalarda Levene çözümlemesi sonucu normal dağılım gösteren değişkenlerde t-testi çözümlemesinden, normal dağılım göstermeyen değişkenlerde ise Mann-Whitney U ve Kruskal Wallis $H$ testlerinden yararlanılmıştır. Tüm çözümlemeler ölçeğin tamamı için olduğu gibi alt boyutları için de gerçekleştirilmiştir. Pedagojik formasyon programı öğretmen adayları ile lisans programı öğretmen adaylarının karşılaştırılması sadece öğrenim gördükleri öğretmen yetiştirme programları çerçevesinde gerçekleştirilmiş, diğer değişkenlere yönelik karşılaştırmalar tüm çalışma grubunu betimleyecek şekilde gerçekleştirilmiştir. Katılımcıların "Internet Kullanım Sıklığı" değişkenine ait karşılaştırılmasında sayıca az olmasından dolayı "Hiç" ve "Nadiren" yanıtını veren katılımcılar birleştirilerek çözümleme gerçekleştirilmiştir.

\section{Bulgular ve Yorum}

Çalışmanın bu bölümünde elde edilen veriler dört alt problem çerçevesinde ele alınmış, bulguların ve yorumların verilişinde alt problemlerin veriliş sırası dikkate alınarak buna uygun bir sıra izlenmiştir.

\section{Birinci Alt Probleme İlişkin Bulgular ve Yorum}

Araştırmanın birinci alt problemi "Öğretmen adaylarının dijital okuryazarlık düzeylerine ilişkin puanlarının dağılımı nedir?” şeklinde belirlenmiştir. $\mathrm{Bu}$ noktada öğretmen adaylarının ölçekten aldıkları puanlar ölçek genelinde ve ölçek alt boyutlarında hesaplanmış, puanların dağılımı Tablo 4'te gösterilmiştir. Tabloda olası puanlar başlığı ile verilen sütunda ölçekten alınabilecek en düşük ve en yüksek değerlere yer verilmektedir. 


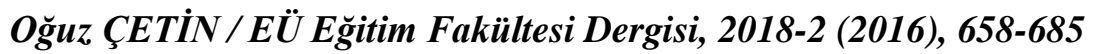

Tablo 4. Dijital Okuryazarlık ve Alt Boyutlarına İlişkin Puanların Dağılımı

\begin{tabular}{cccccccc}
\hline Ölçek & $\mathrm{n}$ & $\bar{X}$ & Mod & Medyan & ss & $\begin{array}{c}\text { En düşük- } \\
\text { en yüksek } \\
\text { puanlar }\end{array}$ & $\begin{array}{c}\text { Olas } \\
\text { puanlar }\end{array}$ \\
\hline $\begin{array}{c}\text { Tüm Ölçek } \\
\text { (Dijital } \\
\text { Okuryazarlık) }\end{array}$ & 202 & 398,40 & 463,00 & 407,00 & 69,46 & $\begin{array}{l}105,00- \\
500,00\end{array}$ & $\begin{array}{c}100,00- \\
500,00\end{array}$ \\
\hline $\begin{array}{c}\text { Bilgisayar } \\
\text { Okuryazarlığ1 }\end{array}$ & 202 & 101,30 & 125,00 & 104,00 & 18,66 & $\begin{array}{l}28,00- \\
125,00\end{array}$ & $\begin{array}{c}25,00- \\
125,00\end{array}$ \\
\hline $\begin{array}{c}\text { Bilgi Okur- } \\
\text { yazarlığ1 }\end{array}$ & 202 & 102,04 & 125,00 & 106,00 & 18,30 & $\begin{array}{l}25,00- \\
125,00\end{array}$ & $\begin{array}{c}25,00- \\
125,00\end{array}$ \\
\hline $\begin{array}{c}\text { Teknoloji } \\
\text { Okuryazarlığ1 }\end{array}$ & 202 & 92,10 & 109,00 & 94,50 & 18,69 & $\begin{array}{l}25,00- \\
120,00\end{array}$ & $\begin{array}{c}24,00- \\
120,00\end{array}$ \\
\hline $\begin{array}{c}\text { Medya Okur- } \\
\text { yazarlığ1 }\end{array}$ & 202 & 102,96 & 130,00 & 106,50 & 20,83 & $\begin{array}{l}26,00- \\
130,00\end{array}$ & $\begin{array}{c}26,00- \\
130,00\end{array}$ \\
\hline
\end{tabular}

Tablo 4'te alınan en düşük ve en yüksek puanlar incelendiğinde, bu puanların ölçek genelinde 105 ile 500 arasında değiştiği görülmektedir. Ölçeğin tamamında ve alt boyutlarında alınabilecek en yüksek puanların alındığı gözlenmektedir. Öğretmen adaylarının ölçeğin tamamından aldıkları puanların aritmetik ortalaması becerileri gerçekleştirme boyutunda "sık sık" ifadesinde alınabilecek toplam puana $(=400)$ çok yakındır. Bu durum ölçeğin alt boyutlarında da benzerlik göstermektedir. Öğretmen adaylarının bilgi okuryazarlığı boyutunda almış oldukları puanların aritmetik ortalaması; becerileri gerçekleştirme boyutunda "sik s1k" seviyesinin üstünde, diğer alt boyutlarda ise "bazen"den "sık sık"a doğru değişim göstermektedir. $\mathrm{Bu}$ sonuç öğretmen adaylarının kendilerini dijital okuryazarlık ve alt boyutları bakımından yeterli düzeyde gördüklerini göstermektedir.

\section{İkinci Alt Probleme İlişkin Bulgular ve Yorum}

Araştırmanın ikinci alt problemi "Öğretmen adaylarının dijital okuryazarlık düzeylerinde cinsiyetlerine göre farklılıklar var mıdır?" şeklinde ifade edilmiştir. Bu amaçla ilk olarak öğretmenlerin ölçeğin tamamından ve alt boyutlarından aldıkları puanların aritmetik ortalamaları hesaplanmış ve t-testi ile cinsiyetler bazında karşılaştırmalar yapılmıştır. Elde edilen sonuçlar Tablo 5'te verilmektedir. 


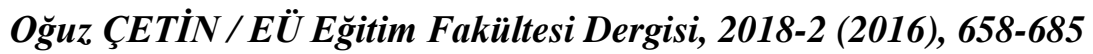

Tablo 5. Öğretmen Adaylarının Dijital Okuryazarlık Düzeyleri ile Alt Boyutlarına Ait Puanlarının Cinsiyetlerine Göre Yapılan t-Testi Çözümlemesi Sonuçları

\begin{tabular}{|c|c|c|c|c|c|c|c|}
\hline Ölçek & Cinsiyet & $\mathrm{n}$ & $\bar{X}$ & ss & sd & $\mathrm{t}$ & $\mathrm{p}$ \\
\hline $\begin{array}{c}\text { Tüm Ölçek } \\
\text { (Dijital Okurya- } \\
\text { zarlık) }\end{array}$ & $\begin{array}{l}\text { Kadın } \\
\text { Erkek }\end{array}$ & $\begin{array}{c}134 \\
68\end{array}$ & $\begin{array}{l}387,83 \\
419,23\end{array}$ & $\begin{array}{l}71,115 \\
61,420\end{array}$ & 200 & $-3,101$ &, $002 *$ \\
\hline $\begin{array}{c}\text { Bilgisayar Okur- } \\
\text { yazarlığı }\end{array}$ & $\begin{array}{l}\text { Kadın } \\
\text { Erkek }\end{array}$ & $\begin{array}{c}134 \\
68\end{array}$ & $\begin{array}{c}98,35 \\
107,12\end{array}$ & $\begin{array}{l}19,061 \\
16,470\end{array}$ & 200 & $-3,229$ &, $001 *$ \\
\hline $\begin{array}{l}\text { Bilgi Okuryazar- } \\
\text { lığı }\end{array}$ & $\begin{array}{l}\text { Kadın } \\
\text { Erkek }\end{array}$ & $\begin{array}{c}134 \\
68\end{array}$ & $\begin{array}{l}100,57 \\
104,94\end{array}$ & $\begin{array}{l}18,860 \\
16,891\end{array}$ & 200 & $-1,612$ & , 109 \\
\hline $\begin{array}{l}\text { Teknoloji Okur- } \\
\text { yazarlığ }\end{array}$ & $\begin{array}{l}\text { Kadın } \\
\text { Erkek }\end{array}$ & $\begin{array}{c}134 \\
68\end{array}$ & $\begin{array}{l}88,87 \\
98,47\end{array}$ & $\begin{array}{l}19,025 \\
16,369\end{array}$ & 200 & $-3,546$ &, $000 *$ \\
\hline $\begin{array}{l}\text { Medya Okurya- } \\
\text { zarlığ }\end{array}$ & $\begin{array}{l}\text { Kadın } \\
\text { Erkek }\end{array}$ & $\begin{array}{c}134 \\
68\end{array}$ & $\begin{array}{l}100,04 \\
108,71\end{array}$ & $\begin{array}{l}21,679 \\
17,842\end{array}$ & 200 & $-2,844$ &, $005^{*}$ \\
\hline
\end{tabular}

Tablo 5'teki bulgular incelendiğinde, öğretmen adaylarının dijital okuryazarlık düzeylerinde cinsiyete göre anlamlı farklılıklar söz konusudur $(\mathrm{p}<.05)$. Erkek öğretmen adaylarının dijital okuryazarlık düzeyleri, kadın öğretmen adaylarının dijital okuryazarlık düzeylerinden anlamlı düzeyde yüksektir. Ölçek alt boyutlarına bakıldığında ise benzer şekilde bilgisayar, teknoloji ve medya okuryazarlığı alt boyutlarında erkek öğretmen adayları lehine anlamlı farklılıklar göze çarpmaktadır. Her ne kadar ölçeğin tamamında ve diğer alt boyutlarında olduğu gibi erkek öğretmen adaylarının aritmetik ortalaması daha yüksek görünse de sadece bilgi okuryazarlığı alt boyutunda cinsiyet açısından anlamlı bir farklılık söz konusu değildir. Erkek öğretmen adaylarının kadın öğretmen adaylarına göre gündelik hayatlarında teknoloji ve özellikle de bilgisayar ortamları ile daha fazla etkileşimde olması bu duruma neden olarak düşünülebilir. Bir sonraki bölümde de tartışılacağı üzere alan yazında bu durumu ortaya koyan pek çok çalışma yer almaktadır. Erkek öğretmen adaylarının kadın öğretmen adaylarına göre teknolojiyi daha etkin kullanıyor olmaları, teknolojik araçları kullanma hususunda daha istekli olmaları ve toplum içerisinde de bu araçları kullanma konusunda teşvik edilmeleri, bilgisayar okuryazarlığı, teknoloji okuryazarlığı ve medya okuryazarlığı düzeylerinde meydana gelen farkın kaynağı olarak düşünülmektedir. 
Ŏğuz ÇETíN / Ë̈U Ĕ̌̆itim Fakültesi Dergisi, 2018-2 (2016), 658-685

\section{Üçüncü Alt Probleme İlişkin Bulgular ve Yorum}

Araştırmanın üçüncü alt problemi "Öğretmen adaylarının dijital okuryazarlık düzeylerinde öğrenim gördükleri öğretmen yetiştirme programına göre farkl1lıklar var mıdır?" şeklinde belirlenmiştir. Özellikle pedagojik formasyon programı fen bilimleri öğretmen adayları ile lisans eğitimi fen bilgisi öğretmen adaylarının dijital okuryazarlık düzeylerinin karşılaştırılmasını içeren bu alt problem önemli görülmektedir. Yapılan t-testi çözümlemesi sonucu elde edilen sonuçlar Tablo 6'da sunulmuştur.

Tablo 6. Öğretmen Adaylarının Dijital Okuryazarlık Düzeyleri ile Alt Boyutlarına Ait Puanlarının Öğrenim Gördükleri Öğretmen Yetiştirme Programına Göre Yapılan t Testi Çözümlemesi Sonuçları

\begin{tabular}{|c|c|c|c|c|c|c|c|}
\hline Ölçek & Program & $\mathrm{n}$ & $\bar{X}$ & ss & sd & $\mathrm{t}$ & $\mathrm{p}$ \\
\hline \multirow{2}{*}{$\begin{array}{c}\text { Tüm Ölçek } \\
\text { (Dijital Okur- } \\
\text { yazarlık) }\end{array}$} & $\begin{array}{l}\text { Pedagojik } \\
\text { Formasyon }\end{array}$ & 124 & 388,59 & 67,390 & \multirow[t]{2}{*}{200} & \multirow[t]{2}{*}{$-2,566$} & \multirow[t]{2}{*}{, $011 *$} \\
\hline & Lisans & 78 & 414,00 & 70,283 & & & \\
\hline \multirow{2}{*}{$\begin{array}{c}\text { Bilgisayar } \\
\text { Okuryazarlığ }\end{array}$} & $\begin{array}{c}\text { Pedagojik } \\
\text { Formasyon }\end{array}$ & 124 & 98,31 & 18,930 & \multirow{2}{*}{200} & \multirow{2}{*}{$-2,931$} & \multirow{2}{*}{, $004 *$} \\
\hline & Lisans & 78 & 106,06 & 17,284 & & & \\
\hline \multirow{2}{*}{$\begin{array}{l}\text { Bilgi Okurya- } \\
\text { zarlığı }\end{array}$} & $\begin{array}{c}\text { Pedagojik } \\
\text { Formasyon }\end{array}$ & 124 & 99,97 & 17,878 & \multirow[t]{2}{*}{200} & \multirow[t]{2}{*}{$-2,045$} & \multirow[t]{2}{*}{, $013^{*}$} \\
\hline & Lisans & 78 & 105,33 & 18,584 & & & \\
\hline \multirow{2}{*}{$\begin{array}{c}\text { Teknoloji } \\
\text { Okuryazarlığ }\end{array}$} & $\begin{array}{c}\text { Pedagojik } \\
\text { Formasyon }\end{array}$ & 124 & 89,52 & 17,967 & \multirow[t]{2}{*}{200} & \multirow[t]{2}{*}{$-2,513$} & \multirow[t]{2}{*}{, $043^{*}$} \\
\hline & Lisans & 78 & 96,22 & 19,200 & & & \\
\hline \multirow{2}{*}{$\begin{array}{l}\text { Medya Okur- } \\
\text { yazarlığ }\end{array}$} & $\begin{array}{c}\text { Pedagojik } \\
\text { Formasyon } \\
\end{array}$ & 124 & 98,79 & 20,675 & \multirow[t]{2}{*}{200} & \multirow[t]{2}{*}{$-1,867$} & \multirow[t]{2}{*}{, $005^{*}$} \\
\hline & Lisans & 78 & 10639 & 20,750 & & & \\
\hline
\end{tabular}

Tablo 6'da verilen bulgular incelendiğinde, öğretmen adaylarının puanlarının öğrenim gördükleri öğretmen yetiştirme programına göre istatistiksel olarak da anlamlı biçimde farklılaştığı görülmüştür $(p<.05)$. Ölçeğin tamamında ve alt boyutlarında lisans eğitimi gören fen bilgisi öğretmen adaylarının artitmetik ortalamalarının, pedagojik formasyon programı fen bilimleri öğretmen adaylarının aritmetik ortalamalarına göre daha yüksek olduğu ve anlamlı farklılıkların lisans eğitimi alan fen bilgisi öğretmen adayları lehine gerçekleştiği görülmektedir. Giriş bölümünde de ifade edildiği 
üzere, pedagojik formasyon eğitimine nazaran lisans eğitiminde daha fazla teknoloji içerikli ders alan fen bilgisi öğretmen adaylarının dijital okuryazarlık düzeylerinin daha yüksek çıkması beklenen bir durum olarak ortaya çıkmaktadır.

Bununla birlikte öğretmen adaylarına sunulmuş olan kişisel bilgi formunda yer alan bilgisayarı ve Internet'i en çok hangi amaçla kullandıkları sorusuna, fen bilgisi öğretmen adaylarının yarıya yakınının $(\% 48,7)$ "Ödev Hazırlama, Bilgi Toplama” yanıtını vermesi ile bu problem çerçevesinde yer alan karşılaştırmalarda fen bilgisi öğretmen adaylarının lehine olan ortalama farklılığı ilişkili görülebilir.

İlkokul ve ortaokul fen bilimleri öğretim programlarında fen derslerinin içeriğine dijital okuryazarlığın kazandırılmasına yönelik beceriler yer almaktadır. Buna bağlı olarak hizmet öncesinde fen bilgisi ögretmen adayları bu konuda daha fazla uygulama olanağı bulmaktadır. Fen bilgisi öğretmen adaylarının ortalamalarının daha yüksek olmasında bu durumun etkili olduğu da düşünülebilir.

\section{Dördüncü Alt Probleme İlişkin Bulgular ve Yorum}

Araştırmanın beşinci alt problemi “Öğretmen adaylarının dijital okuryazarlık düzeylerinde Internet kullanım sıklıklarına göre farklılıklar var mıdır?" şeklinde ifade edilmiştir. Yapılan Levene çözümlemesi sonucu Internet kullanım sıklığı değişkeninin çalışma grubunda normal dağılım göstermemesi nedeni ile Kruskal Wallis $\mathrm{H}$ testi kullanılarak karşılaştırmalar gerçekleştirilmiştir. Elde edilen sonuçlar Tablo 7'de verilmektedir. 


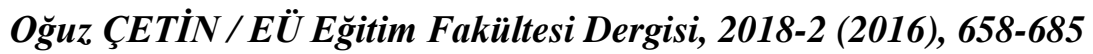

Tablo 7. Öğretmen Adaylarının Dijital Okuryazarlık Düzeyleri ile Alt Boyutlarına Ait Puanlarının Internet Kullanım Sıklıklarına Göre Yapılan Kruskal Wallis H Testi Sonuçları

\begin{tabular}{|c|c|c|c|c|c|c|c|}
\hline Ölçek & Bölüm & $\mathrm{n}$ & $\begin{array}{c}\text { Sira } \\
\text { Ortalamas1 }\end{array}$ & sd & $\chi^{2}$ & $\mathrm{p}$ & $\begin{array}{l}\text { Anlaml } \\
\text { Fark }\end{array}$ \\
\hline \multirow{4}{*}{$\begin{array}{c}\text { Tüm Ölçek } \\
\text { (Dijital Okuryazar- } \\
\text { lık) }\end{array}$} & $\begin{array}{l}\text { Hiç-Nadiren } \\
\text { (A) }\end{array}$ & 10 & 51,80 & \multirow{4}{*}{3} & \multirow{4}{*}{46,566} & \multirow{4}{*}{, $000 *$} & $\mathrm{D}>\mathrm{A}$ \\
\hline & Orta (B) & 63 & 74,94 & & & & $D>B$ \\
\hline & Sik (C) & 60 & 96,50 & & & & $\mathrm{D}>\mathrm{C}$ \\
\hline & Çok Sık (D) & 69 & 137,30 & & & & $\begin{array}{l}\mathrm{C}>\mathrm{B} \\
\mathrm{C}>\mathrm{A}\end{array}$ \\
\hline \multirow{4}{*}{$\begin{array}{l}\text { Bilgisayar Okurya- } \\
\text { zarlığı }\end{array}$} & $\begin{array}{l}\text { Hiç-Nadiren } \\
\text { (A) }\end{array}$ & 10 & 59,10 & \multirow{4}{*}{3} & \multirow{4}{*}{38,375} & \multirow{4}{*}{, $000^{*}$} & $\mathrm{D}>\mathrm{A}$ \\
\hline & Orta (B) & 63 & 74,41 & & & & $\mathrm{D}>\mathrm{B}$ \\
\hline & Sik (C) & 60 & 101,22 & & & & $\mathrm{D}>\mathrm{C}$ \\
\hline & Çok Sık (D) & 69 & 132,62 & & & & $\begin{array}{l}\mathrm{C}>\mathrm{B}, \\
\mathrm{C}>\mathrm{A}\end{array}$ \\
\hline \multirow{4}{*}{$\begin{array}{c}\text { Bilgi } \\
\text { Okuryazarlığ } 1\end{array}$} & $\begin{array}{l}\text { Hiç-Nadiren } \\
\text { (A) }\end{array}$ & 10 & 61,20 & \multirow{4}{*}{3} & \multirow{4}{*}{42,214} & \multirow{4}{*}{, $000 *$} & $D>A$ \\
\hline & Orta (B) & 63 & 76,53 & & & & $\mathrm{D}>\mathrm{B}$ \\
\hline & Sik (C) & 60 & 94,01 & & & & $\mathrm{D}>\mathrm{C}$ \\
\hline & Çok S1k (D) & 69 & 136,65 & & & & \\
\hline \multirow{4}{*}{$\begin{array}{c}\text { Teknoloji Okurya- } \\
\text { zarlığ } 1\end{array}$} & $\begin{array}{l}\text { Hiç-Nadiren } \\
\text { (A) }\end{array}$ & 10 & 56,25 & \multirow{4}{*}{3} & \multirow{4}{*}{37,549} & \multirow{4}{*}{, $000 *$} & $\begin{array}{l}D>A \\
D>B\end{array}$ \\
\hline & Orta (B) & 63 & 76,28 & & & & $\mathrm{D}>\mathrm{C}$ \\
\hline & $\operatorname{Sik}(C)$ & 60 & 99,57 & & & & $\mathrm{C}>\mathrm{B}$, \\
\hline & Çok S1k (D) & 69 & 132,77 & & & & $\mathrm{C}>\mathrm{A}$ \\
\hline \multirow{4}{*}{$\begin{array}{c}\text { Medya } \\
\text { Okuryazarlığ1 }\end{array}$} & $\begin{array}{l}\text { Hiç-Nadiren } \\
\text { (A) }\end{array}$ & 10 & 61,30 & \multirow{4}{*}{3} & \multirow{4}{*}{34,118} & \multirow{4}{*}{, $000 *$} & $D>A$ \\
\hline & Orta (B) & 63 & 80,02 & & & & $\mathrm{D}>\mathrm{B}$ \\
\hline & Sik (C) & 60 & 94,55 & & & & $\mathrm{D}>\mathrm{C}$ \\
\hline & Çok Sık (D) & 69 & 132,98 & & & & \\
\hline
\end{tabular}

Tablo 7'de görüldüğü gibi öğretmen adaylarının Internet kullanım sıklıkları hem tüm ölçek, hem de ölçeğin alt boyutları bakımından $\mathrm{p}<.05$ düzeyinde anlamlı farklılık görülmektedir. Öğretmen adaylarının Internet kullanım sıklıklarına ilişkin ölçekten aldıkları puanlar bakımından yapılan ikili Mann Whitney U karşılaştırmaları incelendiğinde; Internet'i çok sık kullanan öğretmen adaylarının ölçeğin tamamındaki ve alt boyutlarındaki puanlarının, Internet'i sık, orta ve hiç-nadiren kullanan öğretmen adaylarına göre daha yüksek olduğu ve bu farkın $\mathrm{p}<.05$ düzeyinde anlamlı olduğu görülmektedir. Aynı şekilde Internet'i sık kullanan öğretmen 
adaylarının puanları da orta ve hiç-nadiren kullanan öğretmen adaylarına göre dijital okuryazarlık, bilgisayar ve teknoloji okuryazarlığı boyutlarında anlamlı farklılık göstermektedir. Bulgulardan görüleceği üzere öğretmen adaylarının Internet kullanım sıklıkları arttıkça dijital okuryazarlık düzeyleri anlamlı bir biçimde artmaktadır.

\section{Sonuç ve Tartışma}

Teknolojik gelişmelerin yaşantıları etkisi altına aldığı bilişim çağında eğitim ortamlarının teknolojiden bağımsız hareket etmesi neredeyse olanaksızdır. Teknolojinin hayatın her alanında etkin bir biçimde kullanılıyor olması, eğitim kurumlarını da teknoloji entegrasyonunu sağlamaya zorlamaktadır. $\mathrm{Bu}$ noktada eğitim sektöründe görev alan her bir bireyin teknolojiyi etkin olarak kullanabilmesi önem arz etmektedir. Bununla birlikte gelişen teknolojilere bağlı olarak son dönemlerde alan yazında çeşitli okuryazarlık tanımlarına rastlanmaktadır. Bu okuryazarlıklardan birisi de teknoloji kullanım becerilerini ele alan dijital okuryazarlıktır. Özellikle eğitim sektöründe dijital okuryazar öğretmenlerin yetiştirilmesini, görev yapmasını ve bu öğretmenlerin dijital okuryazarlık becerilerini öğrencilerine kazandırmasını konu alan pek çok çalışmaya rastlanmaktadır (Bhatt, 2012; Burnett, 2011; EshetAlkalai, 2004; Eshet-Alkali \& Amichai-Hamburger, 2004; İşçioğlu \& Kocakuşak, 2012; Kıyıcı, 2008; Ng, 2011; Shand ve diğer., 2012). Dijital okuryazarlık becerilerinin fen bilimleri alan eğitimindeki önemi de dikkate alındığında (Ng, 2011), özellikle öğretmen yetiştirme sürecinde yer alan öğretimsel içeriklerin, fen bilimleri ögretmen adaylarına dijital okuryazarlık becerilerini ne derecede kazandırdığının, öğretmen adaylarının kendi perspektiflerinden betimlenmesi önemli görülmektedir.

Bu çalışma kapsamında ülkemizde iki farklı öğretmen yetiştirme programı olan eğitim fakülteleri lisans programları ile pedagojik formasyon eğitimi sertifika programında öğrenim görmekte olan fen bilimleri öğretmen adaylarının dijital okuryazarlık düzeyleri çeşitli değişkenler açısından irdelenmeye çalışılmıştır. Daha önce ifade edildiği üzere bu çalışma öğretmen adaylarının dijital okuryazarlık 
düzeylerini ölçmekten ziyade öğretmen adaylarının dijital okuryazarlık düzeylerine ilişkin öz algılarını ortaya koymaktadır. Elde edilen bulgulardan hareketle her iki programdaki öğretmen adaylarının dijital okuryazarlık düzeyleri de bir bakıma karşılaştırılmış, bu programların dijital okuryazarlık becerilerini kazandırmadaki etkililikleri de ortaya çıkarılmaya çalışılmıştır.

Araştırma kapsamında elde edilen verilerin çözümlenmesi sonucunda çalışma grubunda yer alan öğretmen adaylarının dijital okuryazarlık açısından genel olarak düzeylerini ortaya koyan puan değerleri incelendiğinde; öğretmen adaylarının kendilerini dijital okuryazarlık ve dijital okuryazarlığın alt boyutu olan bilgisayar, bilgi, teknoloji ve medya okuryazarlığı boyutlarında becerileri gerçekleştirme açısından genel itibari ile "sık sık" ifadesinde alınabilecek toplam puana yakın puan aldıklarından, yeterli buldukları görülmüştür (Tablo 4). Bu durum Kazu ve Erten (2014)'in öğretmen ve öğretmen adayları ile gerçekleştirmiş olduğu çalışmada da ortaya konmuştur. $\mathrm{Bu}$ çalışmada da öğretmen ve öğretmen adayları kendilerini dijital açıdan yetkin ve motive edilmiş olarak görmektedir. Benzer şekilde Timur ve diğer. (2014) öğretmen adaylarıyla gerçekleştirmiş oldukları çalışmada öğretmen adaylarının dijital yetkinlik açısından orta düzeyin üzerinde yetkin olduklarını vurgulamaktadır. İşçioğlu ve Kocakuşak (2012) sınıf öğretmeni adayı olan 51 öğrenci ile gerçekleştirmiş oldukları çalışmada da benzer sonuçlara ulaşmışlardır. Çalışma grubuna dahil edilen öğretmen adayları kendilerini dijital okuryazarlık açısından yeterli görmektedirler. Öğretmen adaylarının özellikle bilgi okuryazarlığı boyutunda almış oldukları puanların aritmetik ortalaması becerileri gerçekleştirme boyutunda "sık s1k" seviyesinin üstündedir. Bu durum İşçioğlu ve Kocakuşak (2012) ile Yıldız ve Kaya (2012)'ın çalışmaları ile paralellik göstermektedir.

Araştırmada erkek öğretmen adaylarının kadın öğretmen adaylarına göre dijital okuryazarlık ve alt boyutları olan bilgisayar, teknoloji ve medya okuryazarlığı açısından anlamlı düzeyde daha yüksek ortalamalara sahip oldukları görülmüştür (Tablo 5). Teknoloji kullanımı konusunda erkek öğretmen adaylarının kadın öğretmen adaylarına göre teknoloji bileşenlerine daha fazla merak duymasi, gündelik hayatlarında teknoloji ve özellikle bilgisayar ortamları ile 
daha fazla etkileşimde olması, teknolojik araçları kullanma konusunda daha istekli ve cesaretli olmaları, farklı teknolojileri kullanma boyutunda sürekli teşvik edilmeleri ve teknolojiye kadın öğretmen adaylarına göre daha kolay ulaşmaları bu duruma neden olarak düşünülebilir. Türkiye İstatistik Kurumunun 2015 yılında gerçekleştirmiş olduğu "Hanehalkı Bilişim Teknolojileri Kullanım Araştırması"na göre ülkemizde bilgisayar ve Internet kullanım oranı erkeklerde $\% 64$ ve $\% 65,8$ iken, kadınlarda $\% 45,6$ ve $\% 46,1$ seviyesindedir (TÜİK, 2015). Buradan yola çıkışla erkek öğretmen adaylarının kadın öğretmen adaylarına göre teknolojik araçlara özellikle bilgisayar ve Internet'e daha kolay ulaşabildikleri yorumu yapılabilir. Bununla birlikte çalışma kapsamında ele alınan dijital okuryazarlık düzeyi açısından erkek öğretmen adaylarının anlamlı düzeyde daha yüksek olduğunu ortaya koyan çalışmalar da alan yazında söz konusudur (Kıyıc1, 2008; Timur ve diğer., 2014; Yıldız \& Kaya, 2012).

Türk Eğitim Derneği'nin 2009 yılında yayımlamış olduğu "Öğretmen Yeterlikleri” isimli kitapta, öğretmen yeterlikleri gerek yurt dışı gerekse yurt içi kaynaklardan faydalanılarak pek çok açıdan ele alınmıştır. Bu kitapta öğretimde bilişim teknolojilerinin kullanımı tartışmasız kabul gören bir öğretmenlik yeterliği olarak ifade edilmektedir. Öğretmenler teknolojinin öğrenmeye olan katkısının yanı sıra, teknoloji kullanımındaki sınırlılıkları da dikkate almalı, bilişim teknolojilerinin öğretiminden ziyade; teknolojinin öğretimin geliştirilmesi, bilgi erişimi, yorumlanması ve paylaşımı boyutlarında etkin kullanımı ve öğrencilerin teknoloji kullanımı boyutunda yönlendirilmesi şeklinde bir yaklaşımı benimsemelidir (TED, 2009: 9). Avrupa Konseyi'nin 26 Ekim 2007 tarihinde üye ülkelerin görüş birliği ile öğretmen eğitimi ve yeterlikleri konusunda aldığı kararlar arasında öğretmen yeterlikleri arasında "Mesleki gelişiminde ve çeşitti işleri yaparken bilişim teknolojilerini kullanma" yer almaktadır. Yine Avrupa Parlamentosu'nun 23 Eylül 2008 tarihli “Öğretmen Eğitiminin Kalitesinin Geliştirilmesi" kararı ile öğretmenlerin yeterliklerinin meslek öncesi ve meslekleri boyunca profesyonel gelişimi ile ilgili temel politikalar oluşturulmuştur. Bu kararda da öğretmenlerin bilgi ve iletişim teknolojileri becerilerinin geliştirilmesine vurgu yapılmıştır (TED, 2009: 43). Bu noktada öğretmen yetiştirme programlarının bu 
becerileri ne derecede geliştirdiği önem arz etmektedir. Araştırma kapsamında ülkemizde iki farklı öğretmen yetiştirme programında öğrenim gören eğitim fakültesi lisans eğitimi fen bilgisi öğretmen adayları ile pedagojik formasyon eğitimi fen bilimleri öğretmen adaylarının dijital okuryazarlık düzeyleri bölümler bazında karşılaştırılmış, her iki programı da tamamladığında öğretmenlik yapma hakkı kazanacak olan öğretmen adaylarının birbirlerine göre durumları betimlenmeye çalışılmıştır. Yapılan çözümlemeler sonrasında lisans eğitimi fen bilgisi öğretmen adaylarının dijital okuryazarlık ve onun alt boyutu olan bilgisayar, bilgi, teknoloji ve medya okuryazarlığı puanlarının pedagojik formasyon eğitimi fen bilimleri öğretmen adaylarına göre daha yüksek olduğu ve anlamlılık arz ettiği sonucuna ulaşılmıştır (Tablo 6). Her ne kadar pedagojik formasyon eğitimi alan öğretmen adaylarının teknolojinin eğitimde kullanımına ilişkin -örneğin bilgisayar destekli eğitim- olumlu tutuma sahip oldukları sonucuna ulaşılan çalışmalar söz konusu olsa da (Ateş, Delil, Işlak, \& Savc1, 2015); bu çalışmada da olduğu gibi pedagojik formasyon eğitimi alan öğretmen adaylarının eğitimde teknoloji kullanımı boyutunda kendilerini lisans eğitimi alan öğretmen adaylarına göre yetersiz gördüklerini gösteren çalışmalar söz konusudur. Temiz (2016) pedagojik formasyon eğitimi alan müzik öğretmen adaylarının mesleki yeterliklerini araştırdığı çalışmasında, pedagojik formasyon eğitimi alan öğretmen adaylarının, lisans eğitimi alan öğretmen adaylarına göre kendilerini anlamlı düzeyde daha yetersiz gördükleri sonucuna ulaşmıştır. Aynı çalışmada kullanılan ölçekte yer alan "derslerinde teknolojik araçlar kullanabilme ve kullandırabilme yeteneği" ile "alanıyla ilgili teknolojiden yararlanabilme" maddelerinde, pedagojik formasyon eğitimi alan öğretmen adaylarının aritmetik ortalamaları, lisans eğitimi alan öğretmen adaylarına göre oldukça düşük seviyede çıkmıştır. Delen, Şen ve Erdoğan 2015 yılında pedagojik formasyon eğitimi alan 175 matematik öğretmeni adayı ile gerçekleştirdikleri ve öğretmen adaylarının teknolojik ve pedagojik alan bilgisini irdeledikleri çalışmada, öğretmen adaylarının teknoloji açısından kendilerine güvenmelerine karşın, bu konuda örnek vermeleri istendiğinde zorlandıklarına, katılımcıların yarısından fazlasının teknolojiyi kullanarak bir etkinlik örneği veremediklerine, buna ek olarak bazı öğretmen adaylarının teknolojinin katkısına inanmadıklarına vurgu 
yapmışlardır. Benzer şekilde, Gönen ve Kocakaya (2015) pedagojik formasyon programına katılan öğretmen adaylarının teknopedagojik eğitim yeterliklerini araştırmış oldukları çalışmalarında, öğretmen adaylarının yeterliklerinin orta düzeyde olduğunu saptamışlar, derslerde öğretmen adaylarının yeterliklerini arttıracak etkinlikleri gerçekleştirecek olanakların sağlanmasını önermişlerdir. Burnett (2011) de öğretmen adaylarının dijital okuryazarlıklarını araştırdığ 1 çalışmasında dijital pratiklerin sınıf ortamında uygulanması durumunda öğretmen adaylarına daha iyi bir okuryazarlık kazandırılabileceğine vurgu yapmıştır.

Millî Eğitim Bakanlığı (MEB)'nın Temmuz 2013 itibari ile "Ulusal Öğretmen Strateji Belgesi" çalışmalarında sona gelindiğini ifade etmiştir. $\mathrm{Bu}$ çalışma ile pedagojik formasyon eğitimi yerine "Teknolojik Pedagojik Alan Bilgisi Eğitimi" verileceği vurgulanmaktadır (Yıldırım \& Vural, 2014). Öğretmen adaylarına bu şekilde bir eğitim verildiği takdirde dijital okuryazarlık düzeylerinin artacağı düşünülmektedir.

$\mathrm{Ng} \mathrm{(2011)'ye} \mathrm{göre} \mathrm{öğrencilerin} \mathrm{bilişsel} \mathrm{anlamda} \mathrm{beceri}$ kazanması -onların Web ortamlarındaki bilgiyi kullanması ile ilişkili olan- dijital okuryazarlıklarının gelişmesi ile mümkündür. Web içeriklerinin öğrenciler tarafından zorluk derecesi, güvenirlik, doğruluk ve güncellik gibi çeşitli değişkenler açısından değerlendirilmesi dijital okuryazarlığ geliştirmektedir. Dolayısıyla öğrencinin Internet başında geçirmiş olduğu süre dijital okuryazarlığın gelişiminde etkilidir. Araştırma kapsamında da öğretmen adaylarının dijital okuryazarlık düzeyleri Internet kullanım sıklıklarına göre irdelenmiştir. Internet'i sıkça kullanan öğretmen adayları dijital okuryazarlık açısından, Internet'i orta ve altı seviyede kullanan öğretmen adaylarına göre anlamlı düzeyde kendilerini daha yeterli görmektedir (Tablo 7). Bu durum Ng (2011)'nin çalışmasında ifade ettiklerini desteklemektedir. Kıyıcı (2008) da çalışmasında benzer sonuçlara ulaşmıştır.

\section{Öneriler}

Yapılmış olan bu çalışma farklı öğretmen yetiştirme programlarında öğrenim görmekte olan fen bilimleri öğretmen 
adaylarının dijital okuryazarlık düzeylerini, öğretmen adaylarının kendi perspektiflerinden betimlemeyi amaçlamıştır. Her ne kadar öğretmen adayları kendilerini dijital okuryazarlık açısından yeterli görseler de, uygulama noktasında dijital okuryazarlık becerilerini yordamaya yönelik çalışmalar da planlanmalıdır. Bu şekilde becerileri ne derecede kullanabildikleri de tespit edilebilir.

Teknoloji ile ilgili olarak öğretmen adayları ile gerçekleştirilmiş olan pek çok çalışmada olduğu gibi bu çalışmada da öğretmen adaylarının dijital okuryazarlık düzeylerinin erkek öğretmen lehine olduğu görülmektedir. Kadın öğretmen adaylarının eğitimleri boyunca özellikle teknoloji kullanımına ilişkin olarak, sürece daha etkin katıldıkları eğitim ortamları oluşturulmalıdır.

Çalışmada pedagojik formasyon programında öğrenim görmekte olan öğretmen adaylarının dijital okuryazarlık düzeylerinin, lisans eğitiminde öğrenim görmekte olan öğretmen adaylarına göre daha düşük olduğu tespit edilmiştir. Formasyon programı ders içeriklerine eğitimde teknoloji entegrasyonunu sağlayacak ders içerikleri eklenmelidir. MEB tarafından ifade edilmiş olan "Teknolojik Pedagojik Alan Bilgisi Eğitimi”ne ivedilikle geçilmelidir.

Öğretmen adaylarının Internet kullanım sıklıkları dijital okuryazarlık düzeylerini olumlu yönde etkilemektedir. Öğretmen adaylarının bilgisayar ve Internet'ten daha fazla faydalanacağı, istediği anda hizmet alabileceği, bilgisayar laboratuvarı vb. ortamlar oluşturulmalıdır.

\section{Kaynaklar}

Acharya, K. R., Bautista, J. R., Wilson, J. R., Nahachewsky, J., Briere, J. L., Flanagan, S., . . Pilgrim, J. (2015). Aging, E-literacy, and Technology: Participatory User-Centered Design for Older Adults' Digital Engagement. Journal of Literacy and Technology, $16(2), 3-32$.

Akkoyunlu, B., \& Soylu, Y. (2010). Öğretmenlerin sayısal yetkinlikleri üzerine bir çalışma. Türk Kütüphaneciliği, 24 (4), 748-768.

Ateş, A. M., Delil, A., Işlak, O., \& Savc1, Ü. Z. (2015). Pedagojik formasyon eğitimine katılan öğretmen adaylarının bilgisayar destekli öğretim ile ilgili tutumlarının değerlendirilmesi. $\quad C B \ddot{U}$ Sosyal Bilimler Dergisi, 13 (4), 199-214. doi: 10.18026/cbusos.09930.

Bawden, D. (2001). Information and digital literacies: a review of concepts. Journal of documentation, 57 (2), 218-259. 


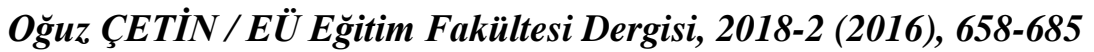

Bhatt, I. (2012). Digital literacy practices and their layered multiplicity. Educational Media International, 49 (4), 289-301. doi: 10.1080/09523987.2012.741199.

Burnett, C. (2011). Pre-service teachers' digital literacy practices: exploring contingency in identity and digital literacy in and out of educational contexts. Language \& Education: An International Journal, 25 (5), 433-449. doi: 10.1080/09500782.2011.584347.

Çetin, O., Çalışkan, E., \& Menzi, N. (2012). Öğretmen adaylarının teknoloji yeterlilikleri ile teknolojiye yönelik tutumları arasındaki ilişki. İlkögrretim Online, 11 (2), 273-291.

Delen, İ., Şen, S., \& Erdoğan, N. (2015). Türkiye'deki formasyon programının incelenmesi: Öğretmen adaylarının teknolojik ve pedagojik alan bilgisi. Necatibey Eğitim Fakültesi Elektronik Fen ve Matematik Eğitimi Dergisi, 9 (2), 252-274.

Ekiz, D. (2009). Bilimsel araştırma yöntemleri (2. Baskı). Ankara: Anı Yayıncılık.

Erkuş, A. (2009). Davranış bilimleri için bilimsel araştırma süreci (2. Baskı). Ankara: Seçkin Yayıncilık.

Eshet-Alkalai, Y. (2004). Digital literacy: A conceptual framework for survival skills in the digital era. Journal of Educational Multimedia and Hypermedia, 13 (1), 93-106.

Eshet-Alkali, Y., \& Amichai-Hamburger, Y. (2004). Experiments in digital literacy. CyberPsychology \& Behavior, 7 (4), 421-429. doi: 10.1089/1094931041774613.

Eshet, Y. (2005). Computers and cognition: Cognitive skills employed in digital work. IADIS Virtual Multi Conference on Computer Science and Information Systems. url:

Gönen, S., \& Kocakaya, F. (2015). Pedagojik formasyon programına katılan öğrencilerinin teknopedagojik eğitim yeterliklerinin çeşitli değişkenlere göre incelenmesi. Eğitim ve Öğretim Araştırmaları Dergisi, 4 (4), 82-90.

Hjørland, B. (2010). Information literacy and digital literacy. Revista PRISMA. COM (7).

İşçioğlu, E., \& Kocakuşak, S. (2012). İlköğretim sınıf öğretmeni adaylarının sayısal okuryazarlık düzeyleri ve teknoloji algıları. Hacettepe Üniversitesi Eğitim Fakültesi Dergisi (Özel Say1 2), 15-24.

Kajee, L., \& Balfour, R. (2011). Students' access to digital literacy at a South African university: Privilege and marginalisation. Southern African Linguistics and Applied Language Studies, 29 (2), 187-196. doi: 10.2989/16073614.2011.633365.

Karasar, N. (2009). Bilimsel araştırma yöntemi (19. Baskl). Ankara: Nobel Yayın Dağıtım.

Kazu, İ. Y., \& Erten, P. (2014). Öğretmen adaylarının sayısal yetkinlik düzeyleri. Bartın Üniversitesi Eğitim Fakültesi Dergisi, 3 (2), 132-152. doi: 10.14686/BUEFAD. 201428175.

Kıyıcı, M. (2008). Öğretmen adaylarının sayısal okuryazarlık düzeylerinin belirlenmesi. Yayımlanmamış doktora tezi, Anadolu Üniversitesi, Eğitim Bilimleri Enstitüsü, Eskişehir

Lankshear, C., \& Knobel, M. (2008). Digital literacies: Concepts, policies and practices (Vol. 30). New York: Peter Lang.

Martin, A. (2005). DigEuLit-a European framework for digital literacy: a progress report. Journal of eLiteracy, 2 (2), 130-136.

Ng, W. (2011). Why digital literacy is important for science teaching and learning: Teaching Science. The Journal of the Australian Science Teachers Association, 57 (4), 26-32.

O'Byrne, W. I. (2016). Perspectives of digital literacies. Literacy Today (2411-7862), 33 (4), 26-26. 


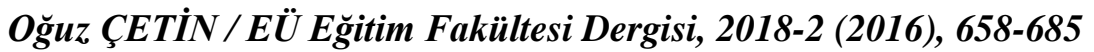

Rosado, E., \& Bélisle, C. (2006). Analysing digital literacy frameworks. A European framework for digital literacy (eLearning Programme 2005-2006)(http://hal. archivesouvertes. fr/docs/00/13/77/79/PDF/Analysing-Edu-Frameworks. pdf).

Shand, K., Winstead, L., \& Kottler, E. (2012). Journey to medieval China: Using technologyenhanced instruction to develop content knowledge and digital literacy skills. The Social Studies, 103 (1), 20-30. doi: 10.1080/00377996.2011.559434.

TED. (2009). Öğretmen Yeterlikleri. Ankara: Türk Eğitim Derneği.

TÜIKK. (2015). Hanehalkı Bilișim Teknolojileri Kullanım Araştırması, 2015. http://www.tuik.gov.tr/PreHaberBultenleri.do?id=18660 adresinden 30.06.2016 tarihinde erişilmiştir.

Temiz, E. (2016). Pedagojik formasyon alan müzik öğretmeni adaylarının mesleki yeterlikleri. Turkish Studies, 11 (3), 2165-2174. doi: 10.7827/TurkishStudies.9139.

Timur, B., Timur, S., \& Akkoyunlu, B. (2014). Öğretmen adaylarının sayısal yetkinlik düzeylerinin belirlenmesi. Muğla Sıtkı Koçman Üniversitesi Sosyal ve Beşeri Bilimler Araştırmaları Dergisi, (33), 41-59.

Webb, M. E. (2005). Affordances of ICT in science learning: implications for an integrated pedagogy. International Journal of Science Education, 27 (6), 705-735. doi: $10.1080 / 09500690500038520$.

Yıldırım, İ., \& Vural, Ö. F. (2014). Türkiye'de öğretmen yetiştirme ve pedagojik formasyon sorunu. Journal of Teacher Education and Educators, 3 (1), 73-90.

Yıldız, Ç., \& Kaya, M. K. M. F. (2012). Siirt ilindeki ortaöğretim öğrencilerinin sayısal okuryazarlık düzeylerinin cinsiyet, sınıf ve öğrenim Gördüğü lise türüne göre farklılaşmasının incelenmesi. Uşak Üniversitesi Sosyal Bilimler Dergisi, (11), 82-96.

\section{Purpose}

\section{Extended Summary}

The fast growing of digital technologies in this era which is called the digital era pits the individuals against the challenge of increasing their skill levels in terms of technical, cognitive and sociological fields in order to come up with solutions to the problems occurring in digital environments. These skills are called as "digital literacy" in the body of literature. The use of information and communication technologies within science education enable students to understand the science education concepts better and motivate them, thus leading to a much more effective science education. At this point, it is significantly important that science education preservice teachers should acquire digital literacy skills. The purpose of this study is to investigate the digital literacy levels of pedagogical formation science education preservice teachers and undergraduate science education preservice teachers receiving education under two different programs in terms of different variables (gender, department and the frequency of having access to Internet).

\section{Method}

A general survey model was used to investigate the digital literacy of preservice teachers. Hence, 128 science education preservice teachers receiving 


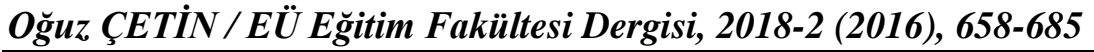

education under pedagogical formation programme and 78 fourth-grade undergraduate science education pre-service teachers at Niğde University, Education Faculty were reached during 2014-2015 academic-year. As data collection tools, "Personal Information Form" developed by Çetin, Çalışkan, ve Menzi (2012) and "Scale to Determine Digital Literacy Levels of Preservice Teachers" which was developed by Kiyıc1 (2008) were used.

\section{Results}

In this research, the following results were obtained; (1) Pre-service teachers see themselves as competent at upper intermediate level about digital literacy. (2) The digital literacy levels of male preservice teachers are higher when compared to female preservice teachers (3) The digital literacy levels of preservice teachers who are receiving undergraduate education were higher when compared with the digital literacy levels of preservice teachers receiving education under pedagogical formation programme (4) The digital literacy levels of pre-service teachers increase positively according to having access to Internet.

\section{Discussion}

Results of the research indicated that pre-service teachers have upper intermediate level competence in terms of digital literacy. It was determined as a result of the study that the digital literacy levels of male pre-service teachers are significantly higher than those of female pre-service teachers. The facts that male pre-service teachers are more curious about technological components when compared to female pre-service teachers, that they are in more interaction with technological components and especially with computers rather than female preservice teachers and that male pre-service teachers are more willing and courageous in terms of using technological components when compared to female pre-service teachers and that they are more motivated and have more easy access to technology when compared to female pre-service teachers can be stated among the reasons behind this phenomenon. As a result of the analyses made, it was concluded that the digital literacy scores of undergraduate science education pre-service teachers were significantly higher than the digital literacy skills of pedagogical programmar science education pre-service teachers. As in this study, there are seminal research studies in the literature stating that pedagogical formation programme science education pre-service teachers see themselves as less competent when compared with the undergraduate science education pre-service teachers. In addition, previous studies and this study have revealed that using Internet frequently increase digital literacy.

\section{Conclusion}

No matter how much the preservice teachers think themselves proficient or adequate in terms of digital literacy skills, studies that seek to focus on predicting the digital literacy skills in terms of practise should be carried out. This way, it can be determined how well and to what extent the teachers can use their skills. Educational environments where the female preservice teachers can participate in 
Ŏğuz ÇETiN / Ë̈ Ĕ̈itim Fakültesi Dergisi, 2018-2 (2016), 658-685

the process, especially the one regarding how to use the technology should be created. The contents of the courses given under the formation programme should be prepared to include a greater number of courses that focus on integrating the technology into education. Educational settings such as computer labs where the preservice teachers could make much more use of computers and Internet, where they can receive instant service anytime they like should be created.

Key Words: preservice teachers, Pedagogical formation programme, digital literacy, technology. 